\title{
自転車振動モデルを用いた 路面平坦性の評価指標構築
}

\author{
岡部光樹 $^{1} \cdot$ 高橋清 $^{2} \cdot$ 富山和也 ${ }^{3} \cdot$ 萩原亨 $^{4} \cdot$ 森石一志 ${ }^{5}$ \\ 1 学生会員 北見工業大学 (下090-8507 北見市公園町 165 番地) \\ E-mail :m1952200061@std.kitami-it.ac.jp \\ 2 正会員 北見工業大学 （干090-8507 北海道北見市公園町 165 番地） \\ 3 正会員 北見工業大学 （广090-8507 北海道北見市公園町 165 番地） \\ 4 フェロー 北海道大学大学院 工学研究院 (下060-8628 札幌市北区北 13 条西 8 丁目) \\ 5 正会員 大林道路株式会社（干530-0047 大阪市北区西天満 1-2-5）
}

\begin{abstract}
近年，全国的にサイクルツーリズムが注目されているため，自転車走行環境に大きく関わる舗装の改善は， サイクルツーリズムの推進において重要になる。しかし, 自転車からみた路面平坦性の評価手法は確立されて いない。そこで本研究では，新たに開発された自転車振動モデルによる実路面のデータにおける再現性検証お よび，自転車版の路面評価指標の構築を行った。その結果，自転車振動モデルは実路面のデータを適用した場 合，モデル開発時と同様に再現性が高いことが示された。 そこで, 開発したモデルを用いて自転車版の路面評 価指標を構築した結果，自転車の乗り心地を反映した值であることが明らかとなった．また，自転車と自動車 では，乗り心地に影響する周波数帯が異なることから，構築した自転車版の路面評価指標であるBRIはIRIに対 する優位性が示された。
\end{abstract}

Key Words : Surface evaluation index, Road surface roughness, Ride quality, Vibration Model

\section{1. はじめに}

近年, 全国的にサイクルツーリズムが注目されている. また，わが国では，2016年に第 8 期北海道総合開発計画 が閣議決定され，サイクルツーリズムの推進を目標に掲 げている1).これを受け, 北海道では, 図-1に示される路 面標示の設置などの施策を行い，自転車走行環境の改善 に取り組んでいる. しかし, 自転車走行の安全性や快適性 に大きく関わる路面平坦性 ${ }^{2}$ は, 既存研究 ${ }^{3}$ により, 評価 手法について検討されているが, 確立には至っておらず, 自転車が走行する車道左側端の舗装は評価されていない． このため, 走行環境の改善に向けた舗装に対する対策は ほとんど行われていない現状にある.

既存の路面評価指標として，国際ラフネス指数（IRI： International Roughness Index）が国際的に用いられている. これは自動車からみた路面評価指標として，世界銀行か ら提案されたものである.IRIはクォーターカー・モデル

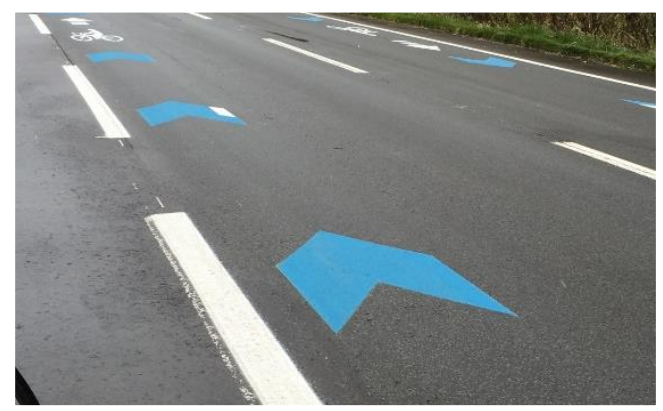

図-1 路面標示

（以下 QC モデル）と呼ばれる，2 軸 4 輪のうち，前輪の 1 輪を取り出した車両振動モデルが， $80 \mathrm{~km} / \mathrm{h}$ で走行した 際のサスペンションストローク累積值を走行延長で正規 化した值と定義され，走行時の乗り心地が反映された值 が算出される指標である ${ }^{4), 5)}$.

自転車からみた路面平坦性の評価に関する研究として 佐々木ら ひ，IRI を用いた自転車走行時の乗り心地評価 


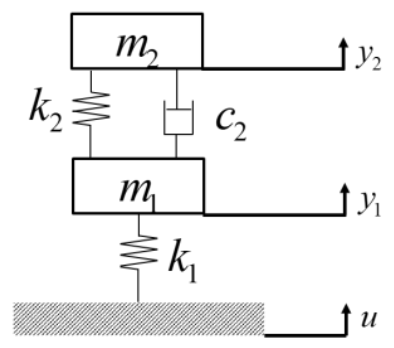

図-2２自由度系自転車振動モデル

表-1 パラメータ一覧 ${ }^{8)}$

\begin{tabular}{|l|r|}
\hline ばね下質量 $m_{1}$ & $13(\mathrm{~kg})$ \\
\hline ばね上質量 $m_{2}$ & $27(\mathrm{~kg})$ \\
\hline 車体ばね定数 $k_{1}$ & $205288(\mathrm{~N} / \mathrm{m})$ \\
\hline ばね上一ばね下間のばね定数 $k_{2}$ & $106592(\mathrm{~N} / \mathrm{m})$ \\
\hline ばね上ーばね下間の減衰係数 $c_{2}$ & $271(\mathrm{~N} \cdot \mathrm{s} / \mathrm{m})$ \\
\hline
\end{tabular}

の可能性を検証したが，IRIが高いにもかかわらず，主観 評価が良い場合が存在し, 整合性の欠ける結果が示され た.このことから，IRIを用いて自転車走行時の乗り心地 を評価することは難しいことが考えられる.よって, 自転 車からみた路面評価を行うには，新たに自転車振動モデ ルを開発する必要があることが明らかとなった。

そこで, 渡辺ら》は, 自転車の振動特性を考慮した自転 車振動モデルを新たに開発するため, 試験路面を自転車 で走行し, 上下加速度を計測する実験を行った. 走行時の 振動特性を基に, 1 自由度系の自転車振動モデルを開発し た. しかし，モデルによるシミュレーションを行ったとこ ろ，実測值に対してシミュレーション值が大きく算出さ れ，良好な結果は得られなかった。 これを受け佐々木ら 8 は, 自転車を振動試験装置に載せて, 加振することで, 自 転車の振動特性の把握を試みた。実験により, 図-2 に示 される自転車前輪部における 2 自由度系の振動モデルを 開発し，表-1 に示されるパラメータを推定した．実験デ 一タによる検証から，振動試験装置上の上下加速度デー タで 10〜30 Hz の上下加速度を再現できることが確認さ れた. しかし, 開発したモデルに, 実道路面のプロファイ ルを入力した場合の上下加速度の再現性は検証されてい ない.

また，自転車からみた路面評価を可能にするためには， 自転車走行時の乗り心地を評価できるようにする必要が ある. 乗り心地の評価に関する研究として, 川越ら ほは, シティサイクルのサドル部における走行時の振動の計測 と, 乗り心地の評価を行った. その結果, $20 \mathrm{~Hz}$ よりも低 周波域が乗り心地と関係を持つことを明らかにしている. しかし, 本研究で対象としているサイクルツーリズムで は, 主に, 長時間の移動に適したクロスバイクやロードバ イクなどのスポーツサイクル 10)が使用されると考えられ る. シティサイクルとスポーツサイクルでは, 自転車の構
造や乗車時の体重のかけ方等の要因で，振動特性に違い があると考えられる. そのため, スポーツサイクルを対象 に乗り心地の評価を可能にする必要がある.

そこで, 本研究では, 本研究グループにより開発された 振動モデル ${ }^{8)}$ に実路面のプロファイルを入力した場合の 再現性を検証寸る. また, 実道路面を自転車で走行したと きの乗り心地を評価する自転車体感評価実験を行う。こ れにより，開発したモデルを用いて自転車版 IRI として BRI (BicycleRideIndex) を構築し，乗り心地との関係性を 分析することで, BRIの妥当性を検証することを目的とす る.

\section{2. 自転車振動モデルの再現性}

\section{(1) 自転車振動モデルの開発方法 ${ }^{8)}$}

\section{a) 実験概要}

加振実験では, 自転車を振動台に載せ, 自転車に人が乗 車した状態で, 自転車前輪部を加振した. その際のハンド ル部, タイヤ部, 振動試験装置における上下加速度を計測 することで，自転車の振動特性を把握する．さらに，モデ ルに使用するパラメータを推定することで，自転車振動 モデルの開発を行っている. 自転車振動モデルは，QC モ デルが自動車の前輪部であることや，乗員は路面からの 振動を前輪部で最初に感じること，ハンドル部に乗員の 体重が大きくかかることを踏まえ，前輪部を対象とした モデルの開発を試みている.

\section{b) 加振条件}

この実験では，より実路面を走行した際の振動に近い 状況を再現させるため, 設定した範囲内の周波数が乱数 プログラムによって変化する, ランダム波にて加振した.

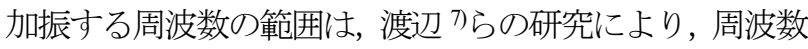
応答関数の振幅が, $20 \sim 30 \mathrm{~Hz}$ 付近で大きいことが確認さ れているため, 5〜30 Hz に設定した.

\section{c) 自転車の振動特性}

実験により得られた上下加速度を基に，周波数応答関 数を算出寸る. 周波数応答関数とは, 自転車をシステムと したときの入力に対する出力の比であり，そのシステム の固有振動数を把握することができる.ここで, 振動試験 装置上での上下加速度のパワースペクトル密度（PSD：

Power Spectrum Density）を入力, 自転車のハンドル部およ びタイヤ部での上下加速度 PSD を出力とすると, 式(1)を 用いて，周波数応答関数を求めることができる.

$$
|H(f)|=\sqrt{P_{y}(f) / P_{x}(f)}
$$

ここで, $|H(f)|$ : 周波数応答関数, $P_{x}(f)$ : 入力の $\mathrm{PSD}$ $\left(\left(\mathrm{m} / \mathrm{s}^{2}\right)^{2} / \mathrm{Hz}\right), P_{y}(f)$ : 出力の PSD $\left(\left(\mathrm{m} / \mathrm{s}^{2}\right)^{2} / \mathrm{Hz}\right)$ である. 


\section{d) 周波数応答関数の算出}

振動試験装置上の上下加速度とハンドル部，タイヤ部 における上下加速度の PSD を算出したのち, 周波数応答 関数を算出した. その結果, $10 \mathrm{~Hz}$ 付近と $20 \mathrm{~Hz}$ 付近の 2 点でピークがみられた. よって, 自転車振動モデルは 2 自 由度系で開発する必要があることが確認された。このモ デルに関する運動方程式は，式(2)，(3)で表せる.

$$
\begin{gathered}
m_{1} \ddot{y}_{1}=k_{1}\left(u-y_{1}\right)+k_{2}\left(y_{2}-y_{1}\right)+c_{2}\left(\dot{y}_{2}-\dot{y}_{1}\right) \\
m_{2} \ddot{y}_{2}=k_{2}\left(y_{1}-y_{2}\right)+c_{2}\left(\dot{y}_{1}-\dot{y}_{2}\right)
\end{gathered}
$$

ここで， $\ddot{y}_{1}$ : ばね下の上下方向加速度 $\left(\mathrm{m} / \mathrm{s}^{2}\right), \dot{y}_{1}$ : ばね 下の上下方向速度 $(\mathrm{m} / \mathrm{s}), y_{1}$ : ばね下の上下方向変位 $(\mathrm{m})$, $\ddot{y}_{2}$ : ばね上の上下方向加速度 $\left(\mathrm{m} / \mathrm{s}^{2}\right), \dot{y}_{2}$ : ばね上の上 下方向速度 $(\mathrm{m} / \mathrm{s}), y_{2}$ : ばね上の上下方向変位 $(\mathrm{m}), u$ : 路面変位 $(\mathrm{m}) k_{1}$ : 自転車車体のば叔定数 $(\mathrm{N} / \mathrm{m}), k_{2}$ : ばね上一ばね下間のばね定数 $(\mathrm{N} / \mathrm{m}), c_{2}$ : ばね上一ばね 下間の減衰係数 $(\mathrm{N} \cdot \mathrm{s} / \mathrm{m})$ である.

\section{e) パラメータ推定}

モデルを開発するにあたって，質量 $m_{1} ， m_{2}$ ，ばね定 数 $k_{1}, k_{2}$, 減衰係数 $c_{2}$ をそれぞれ推定した. 質量は, 自 転車のフロントフォークおよびタイヤの質量と, 自転車 停止時にかかる乗員質量の一部を $m_{1}$, 振動を抑え込む力 によって, ハンドルに伝わる質量と, 自転車停止時にかか る乗員質量の一部の合計を $m_{2}$ とした. この質量を用いて, ばね定数が推定された. また, 減衰係数は渡辺ら》の研究 における段差乗り越え試験の結果を用いて推定した. そ の結果, 各パラメータは表-1 に示される值となっている.

\section{f) 自転車振動モデルの検証}

開発した自転車振動モデルに振動試験装置上の変位デ ータを入力し, シミュレーションを実行することで, ハン ドル部, タイヤ部における上下加速度を算出した. シミュ レーションを実行する際の運動方程式は, MathWorks 社 の MATLAB/Simulink を使用し, ソルバーは Runge-Kutta 法を用いて計算を行った. なお, 本研究においてシミュレ ーションを行う際も, 同様のブロック線図環境および, 方 法を使用した. シミュレーションにより算出された上下 加速度と, 加振時における実測の上下加速度の波形を比 較し，再現性を検証寸る.

\section{g) 入カデータの概要}

シミュレーションには, 振動試験装置上の上下加速度 データを用いた. しかし, 運動方程式を解く上で, 上下加 速度データは変位データに変換する必要がある. そのた め, 累積台形数值積分を行い, 振動試験装置上の変位デー 夕を算出した. また, $5 \mathrm{~Hz}$ 付近で振動試験装置の共振が みられたため, 変位データに $10 \sim 30 \mathrm{~Hz}$ のバンドパスフ イルタを適用し，加振条件として設定した範囲外である $30 \mathrm{~Hz}$ 以上と共振がみられた $10 \mathrm{~Hz}$ 以下の周波数成分を除
去した. さらに, 実際の自転車走行を考える場合, タイヤ の設置長を考慮する必要がある，設置長は実測により $0.06 \mathrm{~m} \sim 0.10 \mathrm{~m}$ であることが確認された．また，自転車走 行時にタイヤと路面の間に粘着力などが作用することを 考慮し, タイヤの設置長を $0.15 \mathrm{~m}$ と仮定し, 入力データ に $0.15 \mathrm{~m}$ のローパスフィルタを適用した.これにより 0.15 $\mathrm{m}$ より短い周波数成分を除去し, 平滑化を行った.

\section{h) シミュレーション結果}

推定したパラメータを用いてシミュレーションを実行 した. その結果, ハンドル部, タイヤ部ともに, シミュレ ーション值と実測值の振幅が一致し，再現性が高いこと

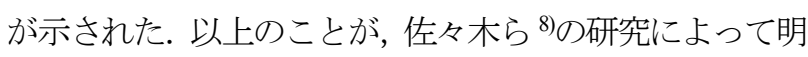
らかとなった. そこで, 次節では, 実路面のデータを入力 した場合における上下加速度の再現性を検証する。

\section{（2）実路面での再現性検証}

モデル開発時は，振動試験装置上の上下加速度データ を用いて再現性を検証した. しかし，開発したモデルを用 いて路面評価を行う際は，実路面のプロファイルを適用 することになる. そのため, 振動試験装置上のデータのみ で再現性を判断するのは適当ではない，そこで本節では， 開発したモデルに実道の路面プロファイルを適用した場 合の再現性を検証する.

\section{a) 検証方法}

本検証では, 開発したモデルに, 試験路面のプロファイ ルを入力する.これにより, シミュレーションを行い, 八 ンドル部における上下加速度を算出する．この上下加速 度と実際に試験路面を走行した際に測定した上下加速度 と比較することで, 再現性を検証する. シミュレーショ ンを実行する際のサンプリング間隔は，算出される上下 加速度の周波数特性が不明であるため, 分析を行ううえ で十分な值と考えられる $1000 \mathrm{~Hz}$ に設定した. また，モデ 儿開発時と条件を合わせるため, 使用する路面プロファ イルと実測の上下加速度には 10〜30 Hz のバンドパスフ イルタと $0.15 \mathrm{~m}$ のローパスフィルタを適用した.

\section{b) 実測の上下加速度データ}

サイクルツーリズムにおいて, 特にスポーツサイクル の経験が少ない人の自転車走行は, 長時間かけて低速で の移動が想定される. このとき, 乗員が無理なく走行でき る速度であり, かつ, 考えられる平均的な速度 ${ }^{11)}$ と判断 し, 走行速度を $15 \mathrm{~km} / \mathrm{h}$ とした. また, 設定した試験路面 を2名の被験者 $\mathrm{A} ， \mathrm{~B}$ が 3 回ずつ走行した。被験者 $\mathrm{A}$ は 再現性の検証を行う際にモデル開発時と同様の条件とす るため, 被験者 B は平均体重に近いため選定した。試験 路面を走行する際, ハンドル部に図-3に示されるように 加速度計（株式会社共和電業：ASW-20A）を取り付け, 走行時の上下加速度を計測した. 被験者はともに 50 代男 性で，被験者 A の体重は $82.9 \mathrm{~kg}$, 被験者 B の体重は, 


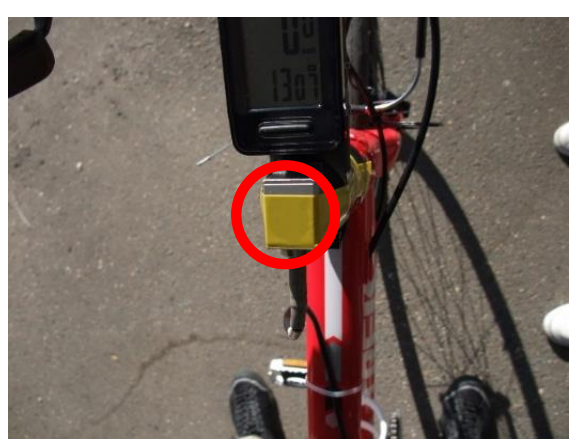

図-3 加速度計取付位置

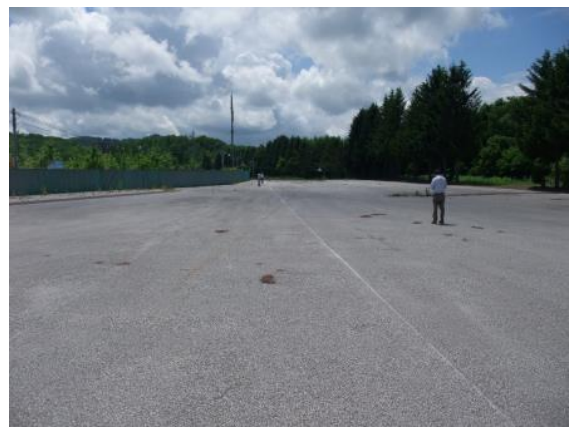

図-4 試験路面の状況

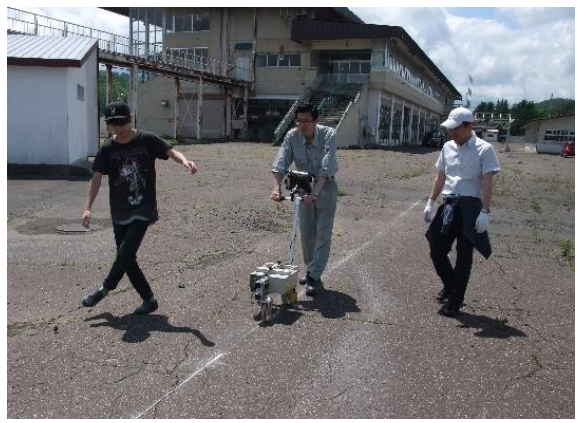

図-5＼cjkstart路面プロファイルの測定

$71.2 \mathrm{~kg}$ である. 本分析では，モデルに用いる質量 $m_{1}$, $m_{2}$ の基となっている被験者 $\mathrm{A}$ の走行により得られた, 上下加速度データを用いることとする. また， 3 回の走行 における上下加速度には，大きな違いがみられなかった ため，代表して 1 つのデータを用いることとする.

\section{c) 路面プロファイルの概要}

検証には，北海道北見市の才ホーツク地域創生研究パ 一クに設定した延長 $100 \mathrm{~m}$ の試験路面のプロファイルを 用いる. 路面プロファイルをモデルに入力する際には, 路 面プロファイルのサンプリング間隔を，距離から 15 $\mathrm{km} / \mathrm{h}$ における時間領域に換算した. 時間領域におけるサ ンプリング間隔は $0.024 \mathrm{~s}$ である. 試験路面の状況を図-4 に示す．プロファイルは手押し式プロファイラ（MRP : TP-1000）を用いて測定し，サンプリング間隔は $0.01 \mathrm{~m}$ と した. 図-5に測定の様子を示す.

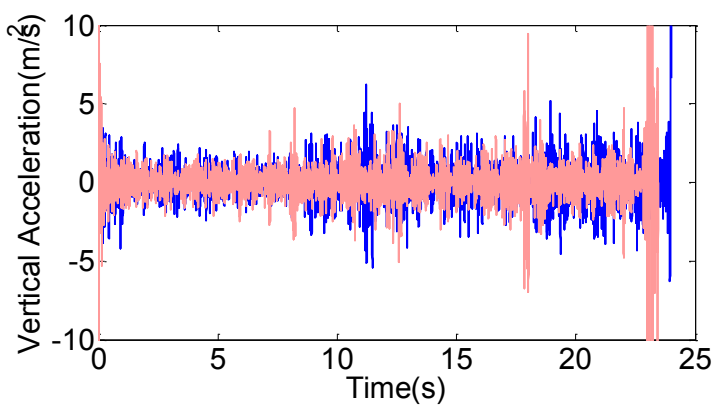

(a) 時間領域での比較

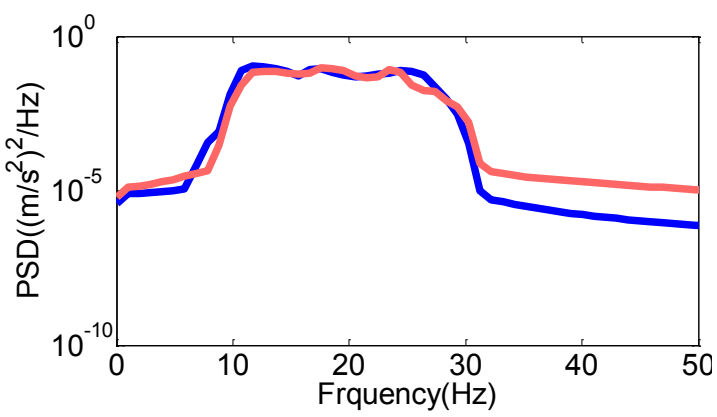

(b) 周波数領域での比較

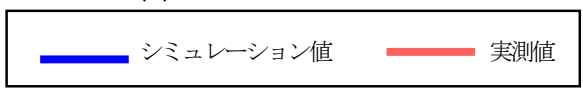

図-6 シミュレーション結果

\section{d) シミュレーション結果}

時間領域で比較した結果を図-6(a)に示す。結果から, シミュレーション值と実測值で同じ振幅值が得られた。 また，周波数領域で比較した結果を図-6(b)に示す。結果 として, モデル開発時と同様に, 自転車の固有振動数が含 まれる 10〜30 Hz の周波数帯においてシミュレーション 值と実測值で同様の周波数特性が得られた.よって開発 したモデルは実道路面においても 10〜30 Hz において再 現性が高いことが明らかとなった。

\section{3. 自転車体感評価実験}

前章により，実道路面の場合でも自転車振動モデルの 再現性が高いことが確認された。しかし，1 章でも述べた ように, 実際に路面評価を行うには, 走行時の乗り心地を 評価する必要がある. そこで, 自転車で実道路面を走行し， その際の乗り心地を評価する自転車体感評価実験を行っ た. また，開発したモデルを用いて $B R I$ を算出した。

\section{(1) 実験概要}

a) 被験者

本実験は，22 名の実験参加者で行った（全被験者のう ち, 男性 20 名, 女性 2 名, 年代は, 20 代が 19 名, 30 代, 50 代， 60 代が 1 名ずつ). 全被験者の内の大多数が，普 

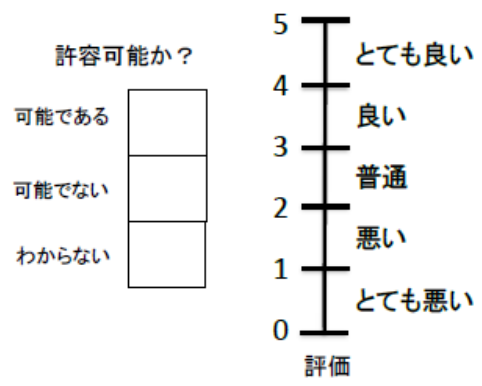

図-7 アンケート様式

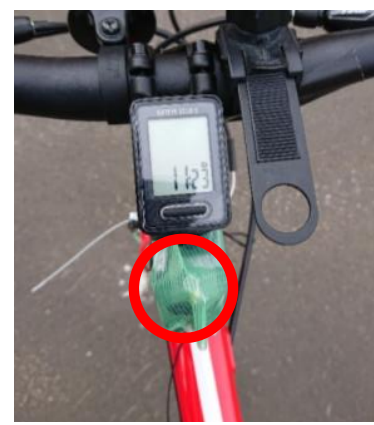

図-8 加速度計取付位置

段はシティサイクルを使用しており，スポーツサイクル の経験は少ない.

\section{b) 主観評価アンケート調査}

本実験では，被験者が 1 区間走り終えるごとに，振動 に対する乗り心地の評価を 5 段階（5：「とても良い」， 4 :

「良い」, 3:「普通」, 2：「やや悪い」，1：「悪い）で行っ た. また, 振動に対して「許容可能である」,「可能でない, 「わからない」の 3 つの選択肢を設定し, 調査した. ア ンケート調査はAASHO Rating Form ${ }^{12)}$ に倣い，図-7 に示 される様式で行った。

\section{c) 実験に用いる自転車}

本実験では, 加振実験時と同様のクロスバイク (TREK: FX3）を使用した. フレームサイズは $44.5 \mathrm{~cm}$ (17.5 イン チ), 質量 $10.3 \mathrm{~kg}$ であり, 実験時のタイヤの空気圧は, 標 準的な空気圧である 8.0 気圧とした.

\section{d) 加速度計取り付け位置}

走行時の上下加速度を計測するため, 本分析では, 振動 モデルの構造に含まれ，人が直接振動を受け取るハンド ル部に加速度計（株式会社リオン：PV-90B）を取り付け た. 加速度計の取り付け位置を図-8 に示す. 加速度計の サンプリング間隔は上下加速度を記録するデータレコー ダー（リオン株式会社: DA-21）の設定に従い，十分な精 度で上下加速度を計測できるよう $1280 \mathrm{~Hz}$ に設定した。

\section{e) ビデオカメラの設置}

自転車が走行した位置を把握するため, 自転車のハン ドル部にビデオカメラ (SONY : HDR-AS300) を設置し, 走行中に録画を行った.

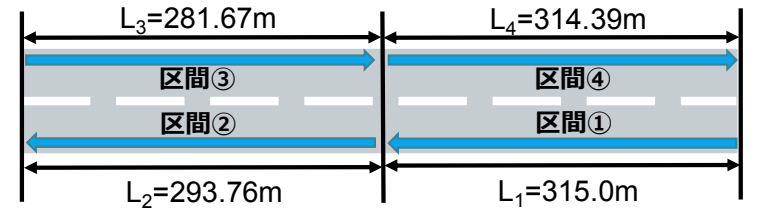

図-9 試験路面図

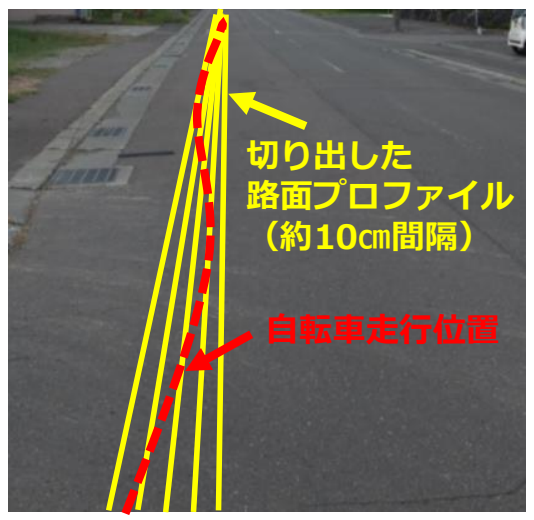

図-10 走行位置と切り出し位置のイメージ図

\section{f) 走行条件}

走行時の姿勢は, 立ち漕ぎをせず, サドルに座った状態 とした. 走行速度は $15 \mathrm{~km} / \mathrm{h}$ 程度とし, 自転車に取り付け たサイクルコンピュータにより乗員が走行速度を把握で きるようにした. 走行位置は車道左側端と設定し, データ レコーダーをリュックに入れ，そのリュックを背負った 状態で走行した.

\section{(2) 路面プロファイルと MMS の概要}

本実験は，道道において，図-9 に示されるように試験 路面を 4 区間設定した. なお，各試験路面に段差やポッ トホールなどの局所的破損はみられなかった. 路面延長 は, $300 \mathrm{~m}$ を目安に自転車に搭載したサイクルコンピュー タにより測定した。本研究では, 設定した試験路面を, MMS（Mobile Mapping System）で取得した路面プロファ イルを用いて, BRI を算出する. MMS とは, 車両に GNSS, カメラ，レーザースキャナなどを搭載した移動体計測装 置であり，効率的に路面プロファイルおよび周辺構造物 の三次元点群データを取得できる ${ }^{13)}$.このため, MMS は, 路面プロファイルを一測線ではなく，幅を持たせて任意 のサンプリング間隔で取得できる. 自転車は自動車と比 較して, 走行が蛇行しやすいため, 自転車からみた路面評 価を行う際は，幅を持たせて路面プロファイルを取得す ることが有効であると考えられる. 分析に用いる路面プ ロファイルは, MMS データから図-10に示されるように 自転車が走行した位置を, 各区間で横断方向に約 $10 \mathrm{~cm}$ 間 隔で 5 測線切り出した. 路面の切り出しには，点群デー タ編集可能ソフト CloudCompare を使用した. なお，自転 車の走行位置はビデオカメラにより撮影した映像を用い 
表-2 アンケート調査結果

\begin{tabular}{|l|r|r|r|r|}
\hline & 区間 1 & \multicolumn{1}{|c|}{ 区間 2 } & 区間 3 & 区間 4 \\
\hline MPR & 2.868 & 3.556 & 2.229 & 3.174 \\
\hline
\end{tabular}

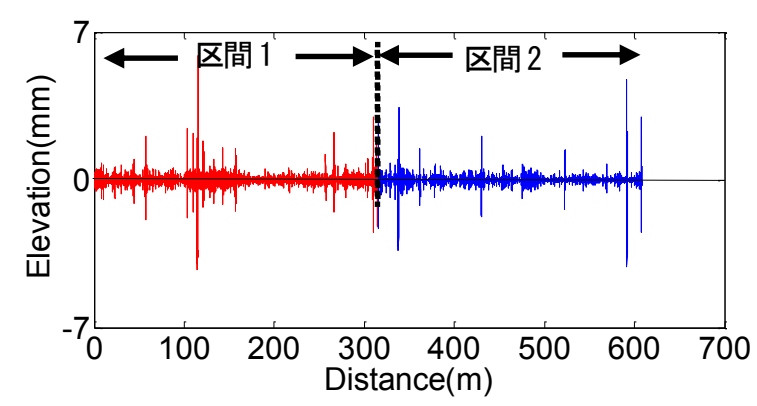

(a) 区間 1, 区間2

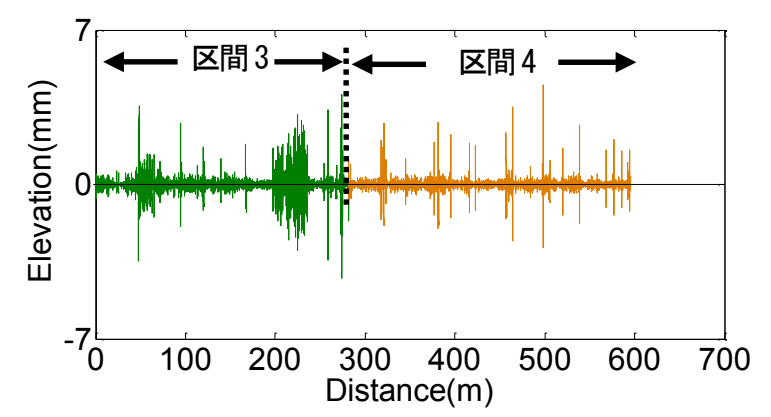

(b) 区間3, 区間 4

図-11 使用する路面プロファイル

て把握した. 切り出した路面プロファイルはサンプリン グ間隔が不均一であったため, MATLAB の interp1 関数を 用いてサンプリング間隔を $0.01 \mathrm{~m}$ に統一した．また,

MMS の特性上, 路面プロファイルに該当しないデータが 存在した. このため, 切り出した 5 つの路面プロファイ ルの内, 有用なデータのみを抽出し, 区間ごとに平均した ものを分析に用いた. なお, 実際に分析を行う際は, 各区 間の始点を $0 \mathrm{~m}$ として基準を設定し, 路面プロファイル を修正した。 また，計測時の誤差により，路面延長は図9 の值であることが，MMS データにより確認された.

\section{(3) アンケート調査結果}

各区間の主観評価の平均值（MPR：Mean Panel Rating) を表-2 に示寸. 結果として, 区間 $3 \rightarrow 1 \rightarrow 4 \rightarrow 2$ の順で評価 が悪いことが示された. 本研究では, この MPR を用い て分析を行う。

\section{(4) BRIの定義および算出方法}

1 章でも述べたように, IRI は $80 \mathrm{~km} / \mathrm{h}$ で走行した際の, サスペンションストローク累積值を走行延長で正規化し て算出される. このIRIの定義に倣い $B R I$ は, $15 \mathrm{~km} / \mathrm{h}$ で 走行した際の, ばね上質量とばね下質量の相対変位の累 積值を走行距離で除した值と定義した. この定義のもと,
表-3 BRI, IRIの算出結果

\begin{tabular}{|l|r|r|r|r|}
\hline & 区間 1 & \multicolumn{1}{|c|}{ 区間 2 } & \multicolumn{1}{|c|}{ 区間 3 } & 区間 4 \\
\hline$B R I(\mathrm{~mm} / \mathrm{m})$ & 7.76 & 5.42 & 12.32 & 6.39 \\
\hline$I R I(\mathrm{~mm} / \mathrm{m})$ & 6.55 & 6.17 & 5.29 & 3.89 \\
\hline
\end{tabular}

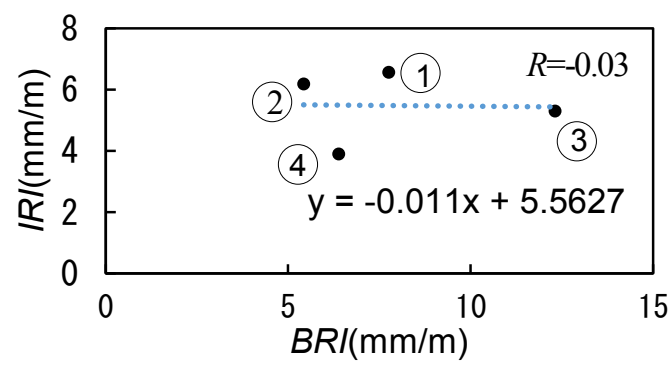

(1) 区間1 (2) 区間2（3) 区間3 (4) 区間4

図-12 BRI とIRIの相関

開発したモデルに路面プロファイルを入力し，シミュレ ーションを実行することで，自転車走行時のばね上とば 水下の変位を算出する. 入力する路面プロファイルのサ ンプリング間隔は 2 章と同様に $15 \mathrm{~km} / \mathrm{h}$ における時間領 域に換算した. また, モデル開発時と同様に, 路面プロフ アイルに 10〜 $30 \mathrm{~Hz}$ のバンドパスフィルタと $0.15 \mathrm{~m}$ のロ 一パスフィルタを適用した。 シミュレーションに使用す る路面プロファイルを図-11 に示す. シミュレーションの サンプリング間翮は $1000 \mathrm{~Hz}$ とし， BRI の評価区間長は, 各区間の全延長とした. BRIの計算式は式(4)で表される.

$$
B R I=\frac{1}{L} \int_{0}^{L / V}\left|\dot{y}_{2}-\dot{y}_{1}\right| d t
$$

ここで， $\dot{y}_{1}$ : ばね下の上下方向速度 $(\mathrm{m} / \mathrm{s}), \dot{y}_{2}$ : ばね上 の上下方向速度 $(\mathrm{m} / \mathrm{s}), \quad L$ : 評価区間長, $V$ : 走行速度 $(\mathrm{m} / \mathrm{s}), t$ : 時間 $(\mathrm{s})$ である. また, IRI も同様の評価区 間長で, 解析フリーソフト ProVAL を用いて算出した. $I R I$ を算出する際は, タイヤの設置長を考慮し, $0.25 \mathrm{~m}$ の ローパスフィルタを適用した.

\section{(5) $B R I ， I R I$ の算出結果およびその関係性}

区間ごとに BRI とIRIを算出した結果を表-3 に示す. 結果として, BRI はIRI よりも大きく算出される傾向が示 された.これは, 本研究て使用した自転車にはサスペンシ ヨンが付いていないことや，自動車よりも質量が小さい ことから，自転車は自動車と比較して走行時における上 下の変位が大きいためと考えられる. また, 算出した $B R I$ とIRIをプロットし，相関係数を算出した結果を図-12に 示寸. その結果, 相関係数は-0.03 と算出されたため, BRI とIRIの間には相関がないことが示された.これは，自転 車と自動車では, 乗り心地に影響を与える路面の特性が 


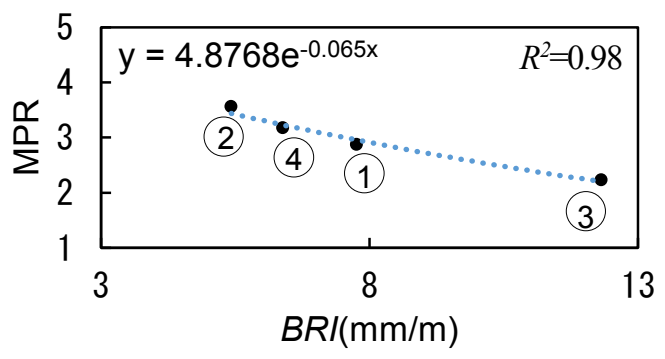

(a) $B R I$

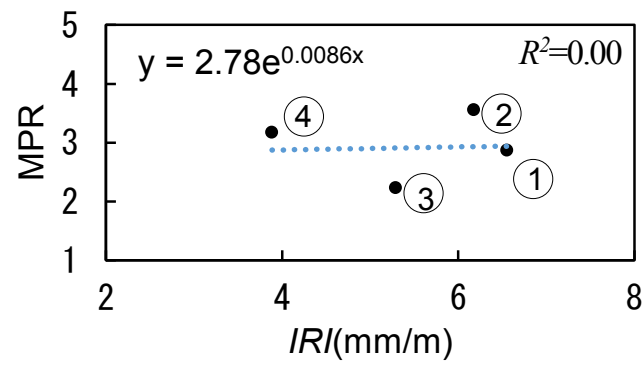

(b) IRI

(1) 区間1 (2) 区間2 (3) 区間3 (4) 区間4

図-13 BRI, IRI と主観評価の相関

違うことが要因だと考えられる. 以上の結果を基に, 次章

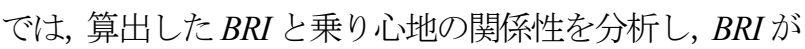
乗り心地を評価できる指標であるか検証する. また, BRI とIRIに相関がない要因を分析するため, 自転車の乗り心 地に影響する周波数帯を明らかにし，自動車との違いを 把握する.

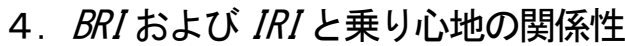

\section{(1) BRI と乗り心地の関係性}

算出した $B R I$ が乗り心地を考慮した值であるかを検証 するため，実験により得られた MPR を目的変数，BRIお よびIRI を説明変数として決定係数を算出寸る. 本分析で は近似曲線が 1 に漸近寸るよう，決定係数は指数近似で 算出する ${ }^{14)}$. その際，分析に用いるデ一タを対数変換し て線形回帰にて算出した。 区間ごとの $B R I$ および IRI に 対する MPR をプロットし, 決定係数を算出した結果を図 -13に示寸. 結果から, BRIは主観評価が悪くなるに従い, 大きく算出される傾向が示され, 決定係数が高く算出さ れた。一方で，IRIは主観評価との相関はみられず，決定 係数は低く算出された. よって, BRI は自転車の乗り心地 を反映した值であることが明らかとなった，また，IRIで は自転車の乗り心地の評価には適さないことが確認され た. そこで，次節では，IRI と BRIで自転車の乗り心地と の相関に差異がある要因について分析する。
Wave Number @ 15km/h(1/m)

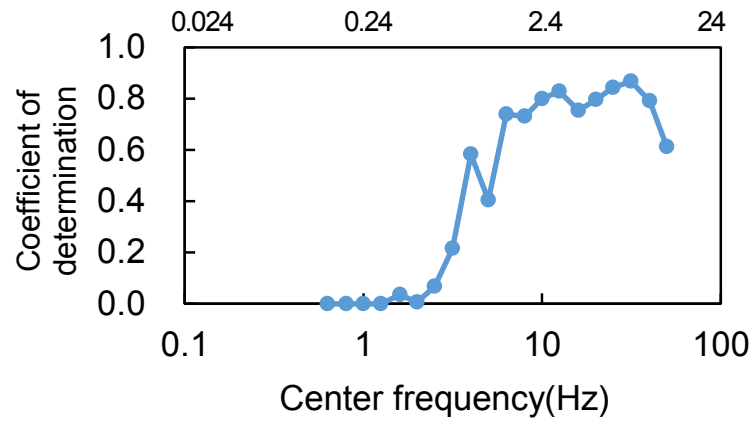

図-14 各中心周波数の決定係数

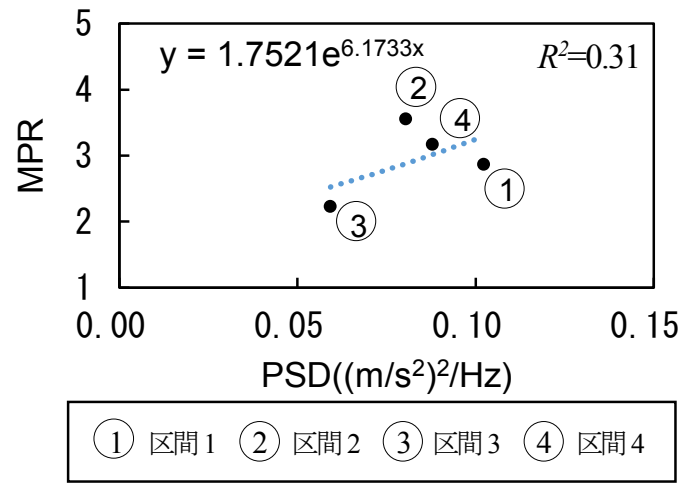

図-15 PSD 值と主観評価の相関 $(1 \mathrm{~Hz})$

\section{（2）上下加速度と乗り心地の関係性}

体感評価実験により得られた上下加速度と主観評価を 基に, 乗り心地に影響する周波数帯を明らかにする. そこ で本研究では, 1/3オクターブバンドごとのPSD值と MPR の決定係数を算出する. オクターブバンドとは, ある周波 数を中心として上限と下限の周波数の比率がちょうど 1 オクターブ (周波数の比率が 2 倍) になる周波数の幅の ことであり，オクターブバンドを $1 / 3$ に分割したものを 1/3 オクターブバンドという．1/3 オクターブバンドは振 動に対する人の体感評価を示す際に用いられ，JIS C $1514^{15)}$ において, 中心周波数とそれに対する下限周波数と 上限周波数が定義されている．その中心周波数ごとに定 められた，下限周波数と上限周波数の間に存在する上下 加速度 PSD 值を抽出し，平均する．これによりその中心 周波数における PSD 值を算出寸る. PSD 值の算出は中心 周波数 $0.63 \mathrm{~Hz}$ から $50 \mathrm{~Hz}$ まで行った。 なお，各中心周波 数における上下加速度 PSD 值は区間ごとに平均したのち, MPR との決定係数を算出寸る．また，本分析では，MPR を目的変数，PSD 值を説明変数とし，本章の 1 節と同様 に，データを対数変換して線形回帰にて決定係数を算出 した.

\section{(3) 決定係数の算出結果}

ハンドル部における $1 / 3$ オクターブバンドの各中心周 波数の PSD 值と MPR の決定係数を算出した結果を図-14 
に示す，なお，振動が乗り心地に影響寸る場合, PSD 值 が大きくなるほど主観評価は悪くなると考えられる。 そ のため, 図-15 のように PSD 值が大きくなるほど，主観 評価が良くなり, 正の相関がみられた場合は, 乗り心地に 影響していないと判断し, 決定係数を 0 とした. 結果と して, 10〜30 Hz 付近において主観評価が悪くなるほど PSD 值が大きくなり, 決定係数が約 0.8 と高い負の相関

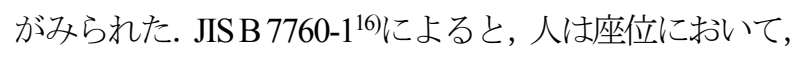
$4 \sim 8 \mathrm{~Hz}$ 付近の振動で高い感度を持つことが示されてい る. そのため, 自動車乗車時においては着座部における 4 〜 8Hz の振動が乗り心地に影響する. 一方で, JISB 7761177によると, 手や腕においては $11 \mathrm{~Hz}$ 付近の振動で高い 感度をもつことが示されている.このため, ハンドル部で は4 8 $\mathrm{Hz}$ ではなく, $11 \mathrm{~Hz}$ 付近の周波数帯において相関 が高くなったと考えられる.したがって, 自転車のハンド ル部に着目した場合, 自転車と自動車では, 乗り心地に影 響する周波数帯が異なることが明らかとなり，図-12にお いて決定俰数に差異があることは妥当な結果であると判 断できる. よって, 自転車版の路面評価指標である BRI は IRIに対する優位性が示された.

\section{5. おわりに}

本研究では, 開発された振動モデルの実路面における 再現性の検証や自転車からみた路面評価指標の構築を行 った. 本研究により得られた知見を以下に示寸.

(1) 自転車加振実験により開発されたモデルは実路面の データを入力した場合においても，10～ $30 \mathrm{~Hz}$ にお いて再現性が高いことが明らかとなった。

（2）開発したモデルを用いて，BRI を算出した結果，IRI に比べて大きい值が算出される傾向が示された。 ま た, 主観評価と BRI の決定係数を算出した結果, 主 観評価と BRI の相関は高いことが示された. よって 算出した BRI は乗り心地を反映した值であることが 示唆された. 一方で, IRI と主観評価には相関がみら れず, IRIは自転車の乗り心地評価には適さないこと が明らかとなり，BRIのIRIに対する優位性が示され た.

（3）自転車体感評価実験により, 自転車の乗り心地は, 車 に乗っている時とは違い, 10 30 Hz 付近の振動が影 響していることが示唆された. よって, 自転車と自動 車では, 乗り心地に影響する周波数帯が異なること が明らかとなった。

以上の結果から，開発した自転車振動モデルを用いて 自転車からみた路面平坦性の評価指標が実用可能である ことが明らかとなった. しかし，本研究における BRIの 妥当性の検証は, 4 つ路面データのみで行っている. こ
のため, 本研究で用いた路面とは違う特性を持った路面 データを用いて，さらに妥当性を検証する．その他，BRI の評価区間長の設定や車種による違い等について今後, 分析を行う必要がある. また, 自転車の走行位置が人によ って異なることを考慮して, 評価する位置を検討する必 要がある. そこで, 本研究で用いた MMS による路面測定 が自転車からみた路面評価に有効であると考えられる. よって MMS データを用いた評価方法を構築することで 精度の高い路面評価が可能となる. 本研究成果を活用し, これらの課題を検討寸ることで，自転車からみた路面評 価手法を確立され，自転車走行環境に大きく関わる舗装 の維持, 修繥に寄与寸るものとなる.

謝辞 : 本研究は JSPS 科研費 $18 \mathrm{~K} 04379$ の助成を受けたも のである.また，本研究の実施に際し，北海道開発局の 佐々木優太氏とフューチャーアーキテクト (株) の渡辺健 太氏には多大な助力を受けた．ここに謝意を表する.

\section{参考文献}

1) 国土交通省北海道局 : 北海道総合開発計画

2) 生駒董樹, 浅田拓海, 有村幹治, 亀山修: 車載カメラ動画 による自転車走行時の振動不快度推定手法の開発，土木計 画学研究発表会・講演集, Vol.58, 2018.

3) 日本道路協会: 自転車利用整備のためのキーポイント, 丸 善出版, 2013.

4) 土木学会 : 舗装工学の基礎, 丸善出版, 2012.

5) Sayers, M. W. and Karamihas, S. M.: The Little Book of Profiling, - Basic Information about Measuring and Interpreting Road Profiles, The University of Michigan, 1998.

6) 佐々木優太, 渡辺健太, 高橋清, 萩原亨, 富山和也 : 路面 平坦性に着目した自転車走行環境の評価に関する研究,第 72 回年次学術講演会講演集, 2017.

7) 渡辺健太, 萩原亨, 高橋清, 富山和也, 佐々木優太: 自転車 走行路面の路面平坦性評価に向けた自転車振動モデルに関 する研究, 土木計画学研究発表会・講演集, Vol.56, 2017.

8) 佐々木優太, 高橋清, 富山和也, 萩原亨, 渡辺健太: 路面平 坦性評価のための自転車振動モデルの開発, 土木学会論文 集E1 (舗装工学), Vol.74, No.3, I_85-I_93, 2018.

9）川越信幸, 河村智博, 吉田淮史: 自転車の乗り心地向上に関 する一考察, 日本機械学会 Dynamics\&Design Conference 2011, No.712, pp.1-7, 2011.

10）中嶋悠人, 山中英生, 真田純子: スポーツサイクル利用増進 のための愛好家と利用者の意識分析, 土木計画学研究・論 文集第 30 巻, I_697-I_704, 2013.

11) Silvia Bernardi, and Federico Rupi.: An analysis of bicycle travel speed and disturbances on off-street and on-street facilities, Transportation Research Procedia 5 82 -94, 2015.

12）土木学会 : 路面のプロファイリング入門, 舗装工学ライブ 
ラリー1, 2003.

13）森石一志, 中村博康, 渡邊一弘: 三次元点群データを用いた 新たな路面評価手法の検討, 土木学会論文集 E1 (舗装工学), vol.69, No.3 (舗装工学論文集第 18 巻), I 9-I_16, 2013.

14) 川村彰, 榊本友紀, 大野滋也, 佐藤正和, 鈴木一隆: 道路管 理者から見た高速道路の路面プロファイルについて, 土木 学会舗装工学論文集, 第 5 巻, 2000 .
15) JISC 1514:オクターブ及び1/Nオクターブバンドフィルタ， 2002.

16) JIS B 7760-1：全身振動一第 1 部 : 測定装置, 2004.

17) JIS B 7761-1 : 手腕系振動一第 1 部 : 測定装置, 2004.

\title{
CONSTRUCTION OF EVALUATION INDEX FOR ROAD SURFACE ROUGHNESS BASED ON THE BICYCLE VIBRATION MODEL
}

\author{
Mitsuki OKABE, Kiyoshi TAKAHASHI, Kazuya TOMIYAMA \\ Toru HAGIWARA and Kazushi MORIISHI
}

\begin{abstract}
In recent years, cycle tourism has been attracting attention in Japan. So improvement of pavement, which greatly affects bicycle driving environment, is important in promoting cycle tourism. However, an evaluation of road surface roughness as seen from a bicycle has not been established. this study, we verified the reproducibility of the newly developed bicycle vibration model on the actual road surface, and constructed the road surface evaluation index of the bicycle. As a result, it was shown that the bicycle vibration model had high reproducibility in the model development when actual road surface data were applied. Furthermore, as a result of building the road surface evaluation index of the bicycle version using this model, it became clear that the value reflected ride quality. In addition, since the frequency bands that affect ride quality differ between bicycles and cars, BRI, the road surface evaluation index of the built bicycle version, showed superiority over IRI.
\end{abstract}

